\title{
PENGARUH PELAYANAN DAN ASOSIASI MEREK TERHADAP KEPERCAYAAN PELANGGAN BENGKEL KENDARAAN BERMOTOR DAN DAMPAKNYA TERHADAP PREFERENSI REKOMENDASI
}

\author{
Muhadjir $^{1}$; Febri Rahmawati ${ }^{2}$ \\ ${ }^{1}$ Peneliti pada Balai Besar Riset Sosial Ekonomi Kelautan dan Perikanan \\ ${ }^{2}$ Mahasiswa Universitas Bina Nusantara \\ Muhadjir_nasir@yahoo.com
}

\begin{abstract}
The number of motorcycles being sold in Indonesia keeps increasing every year. Every manufacturer should stand firm on negotiating to what extent service and brand name impact to consumer trust and recommendation preference. This research aims to investigate this issue using path analysis. Sample is taken from community of car garage consumers. Then, data is verified by some statistical tools such as normality, validity and reliability before using path analysis. The research findings confirm that service quality, brand association and consumer trust are very important to attract trust over garage service. Concerning this issue, the researcher contributes some suggestions such as management should increase service quality by doing employee professionalism improvement. For doing this, the firm can exploit on employee training; implementing incentive strategy to motivate employees, exposing openness and positive atmosphere to interact with consumers and the last but not the least, to maintain good relationship for short and long term by providing consumers with a forum-based communication media.
\end{abstract}

Keywords: service, car garage, recommendation preferences

\begin{abstract}
ABSTRAK
Jumlah sepeda motor yang dijual di Indonesia terus meningkat setiap tahun. Setiap produsen harus konsisten terhadap sejauh mana pelayanan dan dampak merek untuk kepercayaan konsumen dan preferensi rekomendasi. Penelitian ini bertujuan untuk menyelidiki masalah ini dengan menggunakan analisis jalur. Sampel diambil dari masyarakat konsumen bengkel mobil. Kemudian, data diverifikasi oleh beberapa alat statistik seperti normalitas, validitas, dan reliabilitas sebelum menggunakan analisis jalur. Hasil penelitian mengkonfirmasi bahwa kualitas pelayanan, asosiasi merek, dan kepercayaan konsumen sangat penting untuk menarik kepercayaan lebih daripada pelayanan bengkel. Mengenai masalah ini, peneliti memberikan kontribusi beberapa saran seperti manajemen harus meningkatkan kualitas pelayanan dengan melakukan peningkatan profesionalisme karyawan. Untuk melakukan hal ini, perusahaan dapat memanfaatkan pelatihan karyawan; menerapkan strategi insentif untuk memotivasi karyawan; memperlihatkan keterbukaan dan suasana yang positif untuk berinteraksi dengan konsumen dan yang terakhir namun bukan yang tidak penting, untuk menjaga hubungan baik untuk jangka pendek dan panjang, dengan menyediakan media komunikasi berbasis forum untuk konsumen.
\end{abstract}

Kata kunci: pelayanan, garasi mobil, preferensi rekomendasi 


\section{PENDAHULUAN}

Sejalan dengan terus bertambahnya jumlah kendaraan bermotor roda dua di jalan kota Jakarta, keberadaan bengkel sebagai penjual jasa perawatan dan perbaikan kendaraan bermotor roda dua juga terus meningkat sehingga berakibat pada semakin ketatnya persaingan dalam industri jasa perbengkelan kendaraan roda dua. Untuk dapat bertahan dalam industri ini, sebuah bengkel yang memberikan jasa perawatan dan perbaikan kendaraan bermotor dituntut untuk memberikan layanan terbaik bagi pelanggannya, agar pelanggannya puas dan memberikan kepercayaan kepada bengkelnya untuk merawat kendaraannya. Masalahnya adalah pelayanan seperti apa yang "terbaik" di mata pelanggan sehingga pelanggan puas dan mempercayakan perawatan kendaraan bermotornya kepada suatu bengkel. Jika suatu bengkel telah dipercaya oleh pelanggannya, akan memungkinkan bagi si pelanggan bengkel tersebut untuk merekomendasikan kepada orang-orang terdekatnya atau menceritakan hal-hal yang positif mengenai bengkel tersebut. Untuk itu, perlu dilakukan kajian yang meneliti pengaruh kualitas pelayanan terhadap kepercayaan konsumen. Mengingat objek penelitian adalah pelanggan sebuah jaringan bengkel kendaraan bermotor roda dua yang sangat dikenal oleh masyarakat Indonesia, maka asosiasi merek digunakan juga sebagai faktor pengaruh sehingga secara lengkap tulisan ini diberi judul "Analisis Pengaruh Pelayanan dan Asosiasi Merek terhadap Kepercayaan Pelanggan Bengkel Kendaraan Bermotor dan Dampaknya terhadap Preferensi Rekomendasi”.

Wykof (dalam Arief, 2006) menyatakan bahwa kualitas pelayanan adalah tingkat keunggulan yang diharapkan dan pengendalian atas tingkat keunggulan tersebut untuk memenuhi keinginan pelanggan. Definisi kualitas pelayanan berpusat pada upaya pemenuhan kebutuhan dan keinginan pelanggan serta penyampaiannya untuk mengimbangi harapan pelanggan (Simamora, 2003). Lovelock (dalam Utami, 2006) mendefinisikan kualitas layanan sebagai perspektif konsumen dalam jangka panjang dan merupakan evaluasi kognitif dari transfer jasa. Kualitas layanan digambarkan secara umum dan menyeluruh dalam jasa. Bahkan, dikemukakan bahwa kualitas layanan dijelaskan sebagai konsepsi multidimensional yang dibangun melalui evaluasi terhadap kontruksi dari sejumlah atribut yang terkait dengan jasa.

Dalam perspektif kualitas jasa, Davin Garvin (dalam Yatmin, 2004), mengemukakan 8 dimensi kualitas jasa yang dapat dirincikan sebagai berikut (1) Performance (kinerja), yaitu kesesuaian produk dengan fungsi utama produk itu sendiri atau karakteristik operasi dari suatu produk; (2) Feature, yaitu ciri khas produk yang membedakan dari produk lain yang merupakan karakteristik pelengkap dan mampu menimbulkan kesan yang baik bagi pelanggan; (3) Reliability (kehandalan), yaitu kepercayaan pelanggan terhadap produk karena keandalannya atau karena kemungkinan kerusakan yang rendah; (4) Conformance (kesesuaian), yaitu kesesuaian produk dengan syarat atau ukuran tertentu atau sejauh mana karakteristik desain dan operasi memenuhi standar yang telah ditetapkan; (5) Durability (daya tahan), yaitu tingkat ketahanan atau berapa lama produk dapat terus digunakan; (6) Service ability, meliputi kecepatan, kompetensi, kenyamanan, kemudahan dalam pemeliharaan, dan penanganan keluhan yang memuaskan; (7) Estetika, yaitu keindahan menyangkut corak, rasa, dan daya tarik produk; dan (8) Perceived, yaitu fanatisme konsumen menyangkut citra dan reputasi produk serta tanggung jawab perusahaan terhadapnya.

Sedangkan menurut Umar (2002:38), ada 5 dimensi penentu kualitas jasa, yaitu (1) Tangibles (bukti fisik), merupakan tampilan fisik dari fasilitas, personalia, dan materi komunikasinya; (2) Reability (kepastian), merupakan kemampuan untuk mewujudkan layanan yang dijanjikan dapat diandalkan dan dilaksanakan secara akurat; (3) Responsibility (daya tahan), merupakan kemauan untuk membantu dan menyediakan jasa yang tepat bagi konsumen; (4) Assurance (keandalan), merupakan pengetahuan dan keramahan pegawai serta kemampuan untuk merebut kepercayaan dan keyakinan konsumen; dan (5) Emphaty (empati), merupakan kepedulian dan perhatian per individu yang 
diterapkan badan usaha dalam menghadapi konsumennya. Dikaitkan dengan karakteristik produk jasa yang menjadi objek penelitian, parameter-parameter yang digunakan pada variabel jasa dalam penelitian ini adalah keberwujudan, keandalan, daya tangkap, jaminan, dan empati.

Durianto, Sugiarto, dan Sitinjak (2004) mengemukakan bahwa asosiasi merek adalah segala kesan yang muncul dalam benak seseorang yang terkait dengan ingatannya mengenai suatu merek. Menurut Tjiptono (2005), asosiasi merek merupakan segala sesuatu yang terkait dengan memori terhadap suatu merek. Asosiasi merek berkaitan erat dengan image merek (brand image), yang didefinisikan sebagai serangkaian asosiasi merek dengan makna tertentu. Asosiasi merek memiliki kekuatan dan akan semakin kuat seiring dengan bertambahnya pengalaman konsumsi dengan merek spesifik. Lebih jauh, Aaker (dalam Rangkuti, 2004) mengemukakan bahwa asosiasi merek dapat menciptakan suatu nilai bagi perusahaan dan para pelanggan karena ia dapat membantu proses penyusunan informasi untuk membedakan merek yang satu dari merek yang lain. Beberapa keuntungan asosiasi merek adalah dapat membantu proses penyusunan informasi, perbedaan, alasan untuk membeli, dan penciptaan sikap atau perasaan positif landasan untuk perluasan.

Menurut Aaeker (dalam Simamora, 2002), sumber-sumber asosiasi yang terkait dengan suatu merek, yaitu (1) Atribut produk (mengasosiasikan atribut atau karakteristik suatu produk merupakan strategi positioning yang sering digunakan. Mengembangkan asosiasi semacam ini efektif karena jika atribut bermakna, maka asosiasi didapat; (2) Atribut tak berwujud (merupakan atribut umum seperti halnya persepsi kualitas, kemajuan teknologi, atau kesan nilai yang mengikhtisarkan serangkaian atribut yang objektif; (3) Manfaat produk bagi pelanggan (karena sebagian besar atribut produk memberikan manfaat bagi pelanggan, maka biasanya terdapat hubungan antara keduanya. Artinya, jika mau membuat asosiasi manfaat, maka mau tidak mau perusahaan juga harus membuat asosiasi atribut sebagai alasannya. Yang ditonjolkan produsen sebenarnya adalah asosiasi manfaat sebab atribut yang dijadikan sebagai alasan seringkali tidak dipahami masyarakat umum; (4) Harga relatif (evaluasi terhadap suatu merek di sebagian kelas produk ini akan diawali dengan penentuan posisi merek tersebut dalam satu atau 2 tingkat harga. Sudah jelas bahwa harga yang dijadikan sebagai sumber asosiasi adalah harga rendah atau harga yang terjangkau. Pengguna "harga terjangkau" sebagai sumber asosiasi akan bermanfaat bila pasar sasaran yang dibidik sensitif terhadap harga dan selisih harga yang ditawarkan cukup berarti bagi konsumen; (5) Penggunaan (pendekatan ini adalah dengan mengasosiasikan merek tersebut dengan suatu pengguna atau aplikasi tertentu. "Saat apa produk digunakan" dapat dipakai menjadi sumber asosiasi produk; (6) Pengguna/pelanggan (pendekatan ini adalah dengan mengasosiasikan merek tersebut dengan suatu penggunaan atau aplikasi tertentu. "Saat apa produk digunakan" dapat dipakai menjadi sumber asosiasi produk; (7) Orang terkenal/khalayak (mengaitkan orang terkenal atau artis dengan sebuah merek dapat mentransfer asosiasi kuat yang dimiliki oleh orang terkenal ke merek tersebut. Ruginya, kalau citra orang itu rusak, maka citra merek juga bisa turun; (8) Gaya hidup/kepribadian (asosiasi sebuah merek dengan suatu gaya hidup dapat diilhami oleh asosiasi para pelanggan merek tersebut dengan aneka kepribadian dan karakteristik gaya hidup yang hampir sama; (9) Kelas sosial (mengasosiasikan sebuah merek menurut kelas produknya akan lebih berhasil apabila merek tersebut merupakan merek pertama pada kategori produk yang bersangkutan; (10) Para pesaing (mengetahui pesaing dan berusaha untuk menyamai atau bahkan mengungguli pesaing dapat dijadikan sebagi sumber asosiasi; dan (11) Negara/area geografis (sebuah negara dapat menjadi simbol yang kuat asalkan memiliki hubungan yang erat dengan produk, bahkan kemampuan syarat yang harus dipenuhi untuk menggunakan suatu negara atau wilayah sebagai sumber asosiasi adalah tempat-tempat yang dijadikan sumber asosiasi harus memiliki citra positif tentang produk yang diiklankan. Asosiasi merek (brand assosiation) merupakan salah satu elemen pembentuk ekuitas merek (brand equity) di samping elemen-elemen lainnya (brand awarness, perceived quality, dan brand loyalty).

Kepercayaan (trust) melibatkan kesediaan seseorang untuk bertingkah laku tertentu karena keyakinan bahwa mitranya akan memberikan apa yang ia harapkan dan suatu harapan yang umumnya dimiliki seseorang bahwa kata, janji, atau pernyataan orang lain yang dapat dipercaya. Kepercayaan 
merupakan persepsi terhadap keandalan dari sudut pandang pelanggan yang didasarkan pada pengalaman, atau mengarah pada tahapan transaksi atau interaksi yang didirikan oleh terpenuhinya harapan kinerja produk dan tercapainya kepuasan. Kepercayaan terbentuk dari kepuasan pelanggan yang kemudian menjadi indikasi awal terbentuknya kesetiaan pelanggan (Ferrina Dewi, 2004). Sedangkan Irawan (2002) mendefinisikan kepuasan konsumen sebagai hasil akumulasi dari konsumen/pelanggan dalam menggunakan produk dan jasa. Oleh karena itu, setiap transaksi akan memberikan pengaruh terhadap kepuasan konsumen karena kepuasan konsumen mempunyai dimensi waktu karena hasil akumulasi. Kepuasan pelanggan merupakan kunci bagi retensi pelanggan terhadap produk pesaing. Kotler (2000) mengemukakan bahwa pelanggan yang puas akan tetap setia lebih lama, membeli lebih banyak ketika perusahaan memperkenalkan produk baru dan memperbaharui produk-produk yang ada, membicarakan hal-hal yang baik tentang perusahaan dan produk-produknya, memberi perhatian yang lebih sedikit kepada merek-merek dan iklan-iklan pesaing serta kurang peka terhadap harga, menawarkan gagasan jasa atau produk kepada perusahaan, dan biaya untuk pelayanan lebih kecil dibandingkan pelanggan baru karena transaksi yang sudah rutin.

Wicaksono dan Ihalauw (2005) dalam tulisan yang berjudul "Pengaruh Persepsi Kualitas Layanan terhadap Kepuasan dan Dampaknya pada Preferensi Rekomendasi", menuliskan preferensi rekomendasi merupakan suatu sikap dari konsumen yang bersedia memberikan rekomendasi terhadap produk dan jasa yang pernah dinikmatinya kepada orang lain. Lebih lanjut diketahui beberapa indikator preferensi rekomendasi, yakni (1) Pelanggan bersedia memberikan rekomendasi positif mengenai jasa yang telah dikonsumsi, (2) Pelanggan mendorong keluarga/teman untuk menggunakan jasa yang telah dikonsumsi, (3) Pelanggan akan menceritakan hal-hal positif mengenai jasa yang telah dikonsumsi, dan (4) Konsumen hanya akan selalu merekomendasikan penyedia jasa tertentu kepada keluarga/teman.

\section{METODE PENELITIAN}

Penelitian ini bertujuan untuk menganalisis pengaruh kualitas layanan dan asosiasi merek terhadap kepercayaan konsumen dan dampaknya pada preferensi rekomendasi terhadap bengkel kendaraan bermotor roda dua. Kualitas layanan dalam penelitian ini diukur dengan dimensi karakteristik pelayanan, yaitu keberwujudan, kehandalan, daya tanggap, jaminan, dan empati. Desain penelitian ini adalah desain penelitian asosiatif, yaitu penelitian yang bertujuan untuk mengetahui hubungan antar 2 variabel atau lebih. Metode penelitian yang digunakan adalah metode survei, dengan mempelajari data dari sampel yang diambil dari populasi. Jenis data yang digunakan dalam penelitian ini adalah jenis data kuantitatif, maupun kualitatif dengan sumber data primer yang diambil dari pelanggan terpilih (responden) melalui survei dan data sekunder yang didapat melalui berbagai media melalui studi pustaka.

Pengambilan sampel responden menggunakan pendekatan probability random sampling, di mana setiap individu dalam suatu populasi memiliki peluang yang sama untuk diambil sebagai responden dan tekhnik yang akan digunakan adalah simple random sampling, dengan mengambil secara acak dari populasi yang ada. Pengambilan sampel responden menggunakan rumus Taro Yamane/Slovin. Dengan tingkat kepercayaan sebesar 95\%, tingkat presisi 10\%, dan jumlah populasi (pelanggan) sebanyak \pm 1500 orang, didapat jumlah responden sebanyak 110 orang.

Data yang diperoleh akan diolah dengan menggunakan SPSS (Statistical Program for Social Science) versi 16.0, dengan metode analisis yang digunakan meliputi (1) Uji validitas (untuk mengetahui valid atau tidaknya butir-butir pertanyaan yang tercantum dalam kuesioner yang akan disebarkan kepada responden). Untuk mengetahui valid atau tidaknya pertanyaan dalam kuesioner digunakan teknik analisis korelasi Pearson Product Moment (Umar, 2002); (2) Uji reliabilitas (untuk 
mengetahui reliabel atau tidaknya butir-butir pertanyaan dalam kuesioner untuk menjawab tujuan penelitian). Pengukuran reliabilitas dikur dengan uji statistik Conbrach Alpha; (3) Analisis jalur/Path Análisis (merupakan pengembangan dari analisis regresi yang digunakan untuk menganalisis hubungan kausal antar variabel, di mana variabel-variabel bebas mempengaruhi variabel terikat, baik secara langsung maupun tidak langsung, melalui satu atau lebih variabel perantara) (Tabel 1).

Tabel 1 Operasional Variabel Penelitian

\begin{tabular}{|c|c|c|c|}
\hline $\begin{array}{l}\text { Variabel } \\
\text { Penelitian }\end{array}$ & $\begin{array}{l}\text { Konsep } \\
\text { Variable }\end{array}$ & $\begin{array}{c}\text { Sub } \\
\text { Variabel }\end{array}$ & Indikator \\
\hline $\begin{array}{l}\text { Kualitas } \\
\text { pelayanan }\end{array}$ & $\begin{array}{l}\text { Sejauh mana } \\
\text { kualitas pelayanan } \\
\text { yang diberikan } \\
\text { oleh bengkel }\end{array}$ & $\begin{array}{l}\begin{array}{l}\text { Keberwujudan } \\
\text { (tangibles) }\end{array} \\
\text { Kehandalan } \\
\text { (reability) }\end{array}$ & $\begin{array}{l}\text { 1) Gedung dan fasilitas bengkel yang nyaman dan } \\
\text { bersih } \\
\text { 2) Penampilan karyawan bengkel yang bersih dan sopan } \\
\text { 3) Penempatan barang bengkel yang tertata secara } \\
\text { sistematis sesuai dengan jenis barang } \\
\text { Kelengkapan barang pada bengkel yang sesuai } \\
\text { dengan kebutuhan }\end{array}$ \\
\hline
\end{tabular}

Skala pengukuran data yang digunakan adalah pengukuran interval menggunakan skala Likert. Teknik skala digunakan untuk mengukur sikap, pendapat, dan persepsi seseorang atau sekelompok orang terhadap objek penelitian. Skala Likert ini berhubungan dengan pernyataan tentang sikap seseorang terhadap sesuatu, misalnya setuju - tidak setuju, senang - tidak senang, dan baik - tidak baik.

\section{HASIL DAN PEMBAHASAN}

\section{Profil Responden}

Dapat diketahui bahwa pelanggan bengkel didominasi oleh laki laki usia produktif yang berpenghasilan tetap dan cukup loyal kepada bengkel. Loyalitas ini perlu tetap dijaga di antaranya melalui forum yang berfungsi sebagai sarana komunikasi dan informasi antara perusahaan dengan pelanggannya (Tabel 2). 
Tabel 2 Profil Responden

\begin{tabular}{|c|c|c|}
\hline No & Atribut profil & $\%$ \\
\hline 1. & Jenis kelamin & \\
\hline 1) & Pria & 76 \\
\hline 2) & Wanita & 24 \\
\hline 2. & Jenis pekerjaan & \\
\hline 1) & Pegawai negeri/swasta & 52 \\
\hline 2) & Wiraswasta & 29 \\
\hline 3. & Usia & \\
\hline 1) & 21 tahun -29 tahun & 55 \\
\hline 2) & Di atas 30 tahun & 22 \\
\hline 4. & Pengeluaran perbulan & \\
\hline 1) & 3,1 juta -10 juta & 64 \\
\hline 2) & Di atas 10 juta & 11 \\
\hline 5. & Pengeluaran untuk perawatan motor per tahun & \\
\hline 1) & 500 ribu $-2,5$ juta & 67 \\
\hline 2) & 2,6 juta -5 juta & 7 \\
\hline 6. & Jumlah penggunaan jasa perawatan bengkel & \\
\hline 1) & 3 kali - 10 kali & 49 \\
\hline 2) & Di atas 10 kali & 48 \\
\hline
\end{tabular}

Sumber: data primer, diolah

\section{Hasil Uji Validitas Kuesioner}

Uji validitas dilakukan dengan membandingkan nilai $t_{\text {hitung }}$ dengan nilai $\mathrm{t}_{\text {tabel }}$, dengan $\mathrm{N}=30$, maka didapatkan nilai $\mathrm{t}_{\text {tabel }}$ 0,311. Hasil pengujian menunjukkan bahwa nilai $\mathrm{t}_{\text {hitung }}$ seluruh pertanyaan/indikator pembentuk variabel independen dan dependen nilainya lebih besar daripada $t_{\text {tabel }}$ $\left(\mathrm{t}_{\text {hitung }}>\mathrm{t}_{\text {tabel }}\right)$, maka dapat disimpulkan bahwa seluruh pertanyaan dalam kuesioner adalah valid sehingga dapat digunakan sebagai alat ukur.

\section{Hasil Uji Reliabilitas Kuesioner}

Uji reliabilitas dilakukan untuk mendapatkan tingkat ketepatan (keajegan) alat pengumpul data (kuesioner) yang digunakan. Pertanyaan dalam kuesioner reliabel jika nilai Cronbach's Alpha indikator pembentuk variabel adalah $\geq 0,60$. Menggunakan perangkat analisis SPSS 16.0 menunjukkan nilai Cronbach's Alpha seluruh variabel di atas 0,60 sehingga dapat disimpulkan bahwa kuesioner dapat digunakan sebagai alat pengumpul data.

\section{Analisis Korelasi Antar Variable Dependen dan Independen}

Kriteria penilaian kuat lemahnya korelasi hubungan antar variable dilihat dari angka korelasi Pearson dengan penilaian sebagai berikut:

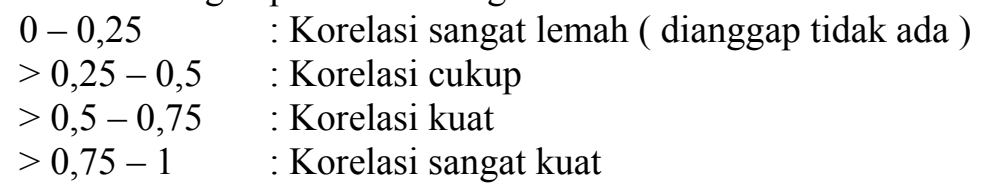

Hasil pengujian menggunakan SPSS 16.0 menghasilkan nilai nilai korelasi Pearson, yaitu korelasi antara korelasi kualitas pelayanan dengan kepercayaan konsumen $(0,501)$, dan korelasi antara asosiasi merk dengan kepercayaan konsumen $(0,532)$; dapat disimpulkan bahwa korelasi antar variabel dependen dengan variabel independen termasuk kategori kuat karena berada di atas 0,5 tetapi masih di bawah 0,75 . 


\section{Analisis Pengaruh Kualitas Pelayanan dan Asosiasi Merek terhadap Kepercayaan Konsumen}

Pengujian dilakukan dengan menggunakan uji F. Menggunakan SPSS 16.0 didapatkan Fhitung $25.350>$ Ftable (k, n-k-1 adalah 2, 107) sebesar 3.09 sehingga dapat disimpulkan kualitas pelayanan dan asosiasi merek berpengaruh dan signifikan terhadap kepercayaan konsumen.

Pengujian Sub - struktur 1

Persamaan sub - struktur 1: $\mathrm{Y}=0.262 \mathrm{X} 1+0.357 \mathrm{X} 2+0.824$ ع 1

$\mathrm{R}^{2} \mathrm{yx} 1 \mathrm{x} 2=0.315$

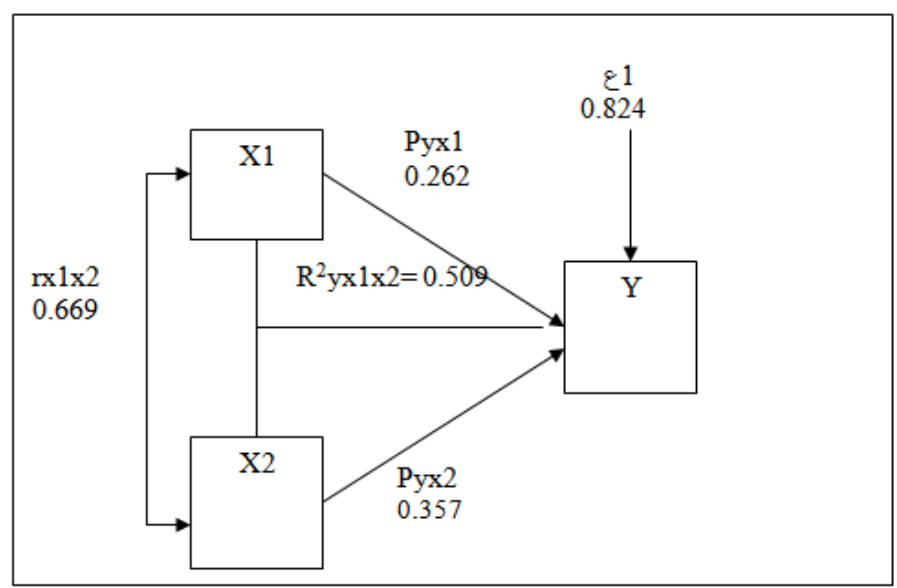

Sumber: data primer, diolah

Gambar 1 Diagram Jalur Sub - struktur 1

Pengujian sub - struktur 2

Persamaan sub - struktur 2: $Z=0.262 \mathrm{X} 1+0.357 \mathrm{X} 2+0.304 \mathrm{Y}+0.700 \_2$

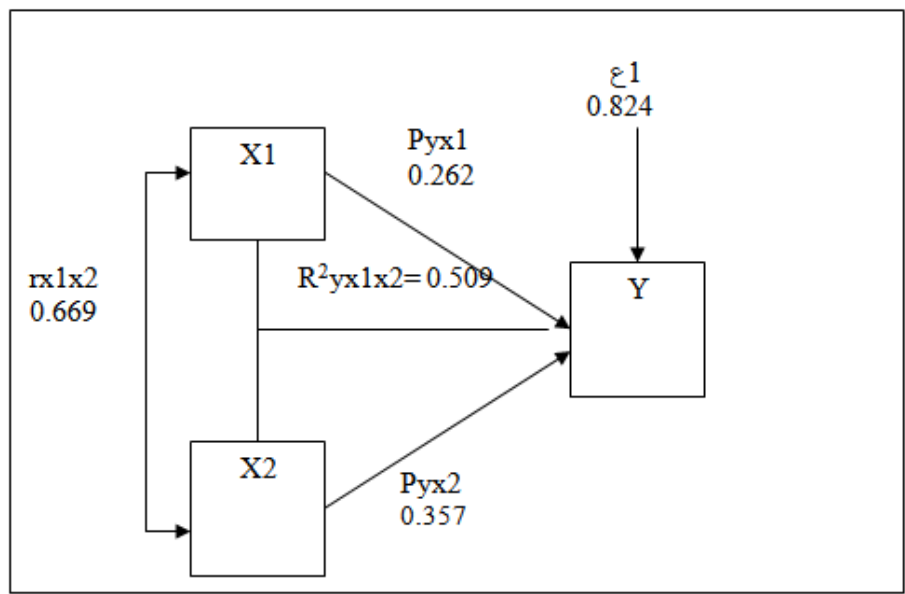

Sumber: data primer, diolah

Gambar 2 Diagram Jalur Sub - struktur 2 
Berdasarkan Gambar 1 dan 2 di atas, diketahui besaran/nilai koefisien jalur, pengaruh langsung dan tidak langsung serta pengaruh total variabel variabel penelitian seperti pada Tabel 3 .

Tabel 3 Rangkuman Pengaruh Antar Variabel

\begin{tabular}{ccccc}
\hline \multirow{2}{*}{ Variabel } & Koefisien Jalur & Pengaruh \\
\cline { 3 - 5 } & & Langsung & $\begin{array}{c}\text { Tidak Langsung } \\
\text { Melalui Y }\end{array}$ & Total \\
\hline X1 & 0.262 & $0.2621)$ & $0.10096)$ & 0.3629 \\
X2 & 0.357 & $0.3572)$ & $0.06417)$ & 0.4211 \\
Y & 0.304 & $0.3043)$ & - & 0.304 \\
Y1 & & $0,3324)$ & & \\
Y2 & & $0,2115)$ & - \\
ع1 & 0.824 & $0.824^{2}=67.8$ & - & - \\
ع2 & 0.700 & $0.700^{2}=49$ & - & \\
\hline
\end{tabular}

Sumber: data primer, diolah

\section{Keterangan:}

Pengaruh langsung variabel kualitas pelayanan terhadap kepercayaan konsumen (Pyx1)

Pengaruh langsung variabel asosiasi merek terhadap kepercayaan konsumen (Pyx2)

Pengaruh variable kepercayaan konsumen terhadap preferensi rekomendasi (Pyz)

Pengaruh langsung variabel kualitas pelayanan terhadap preferensi rekomendasi (Px1Z)

Pengaruh variable asosiasi merek terhadap preferensi rekomendasi (Px2Z)

Pengaruh variabel kualitas pelayanan terhadap preferensi rekomendasi melalui kepercayaan konsumen --- $\mathrm{Z} 1=(0.332 \mathrm{x} 0.304)=0.1009$

Pengaruh variabel asosiasi merek terhadap preferensi rekomendasi melalui kepercayaan konsumen ---$\mathrm{Z} 2=(0.211 \times 0.304)=0.0641$

\section{SIMPULAN}

Hasil penelitian menunjukkan bahwa kualitas pelayanan, asosiasi merek, dan kepercayaan konsumen penting untuk menjadi perhatian perusahaan jasa perbengkelan kendaraan bermotor roda dua, dalam upaya meningkatkan kinerja dan keberlanjutan perusahaan. Penting menjadi perhatian karena terbukti bahwa ketiga hal tersebut mempengaruhi pelanggan dalam merekomendasikan jasa bengkel kepada teman dan kerabatnya. Berkaitan dengan hal di atas dan merujuk kepada pilihan jawaban responden (pelanggan) terhadap pertanyaan pertanyaan dalam kuesioner, beberapa saran yang dapat dilakukan oleh perusahaan jasa perbengkelan adalah (1) Pihak manajemen perlu meningkatkan kualitas pelayanan dengan cara meningkatkan profesionalisme karyawan dengan cara memberikan pelatihan berkala dan bertingkat kepada karyawan bengkel, menetapkan strategi insentif yang menarik dan baik untuk masing-masing karyawannya agar karyawan lebih termotivasi untuk memberikan pelayanan yang terbaik kepada pelanggan, memberikan suatu program atau acara untuk karyawan yang bertujuan untuk meningkatkan loyalitas dan terbentuknya mental positif seperti keterbukaan dan kejujuran yang nantinya akan berpengaruh positif terhadap interaksi dengan pelanggan; (2) menjaga hubungan baik dan jangka panjang dengan pelanggan dengan menyediakan forum yang dapat berfungsi sebagai media komunikasi dengan pelanggan. 


\section{DAFTAR PUSTAKA}

Arief, M. (2006). Pemesanan jasa dan kualitas pelayanan, cetakan pertama, Malang: Bayumedia Publising.

Durianto, Darmadi, Sugiarto, dan Sitinjak, T. (2004). Strategi menaklukan pasar melalui riset ekuitas dan perilaku merek, Jakarta: PT Gramedia Pustaka Utama.

Ferrinadewi, E (2004). Brand trus and brand loyalti : is there a link?, Jurnal Ekonomi - Manajemen, Vol 3 No.2.

Irawan, H. (2002). 10 prinsip kepuasan pelanggan. Jakarta : Elex Media Komputindo.

Kotler, P. (2000). Marketing management, $10^{\text {th }}$ td. New Jersey : Prentice - Hall.

Rangkuti, F. (2004). The power of brands: Tekhnik mengelola brand equity dan strategi pengembangan merek, Jakarta: PT Gramedia Pustaka Utama.

Simamora, B. (2002). Aura merek, Jakarta PT Gramedia Pustaka Utama.

Simamora, B. (2003). Memenangkan pasar dengan pemasaran efektif dan profitabel, cetakan kedua, Jakarta: PT Gramedia Pustaka Utama.

Tjiptono, F., dan Chandra, G. (2007). Service quality satisfaction, Yogyakarta: Andi.

Umar, H. (2002). Riset pemasaran dan perilaku konsumen, Jakarta: PT Gramedia Pustaka Utama.

Utami, Whidya, dan Christina. (2006). Manajemen ritel strategi dan impementasi ritel modern, Jakarta: Salemba Empat.

Wicaksono, S.A dan Ihalauw, J.J (2005). Pengaruh persepsi kualitas layanan terhadap kepuasan klien dan dampaknya pada preferensi rekomendasi klien, Jurnal Ekonomi Perusahaan Vol. 12 No.3, September 2005.

Yatmin, Z. (2005). Manajemen kualitas produk dan jasa, cetakan keempat, Fakultas Ekonomi, Universitas Islam Indonesia, Yogyakarta: Ekonisia Kompas. 